\title{
The Integration of Problem Based Learning Model on Indonesian Language E-Modules
}

\author{
Ni Luh Sukareni ${ }^{1}$, Adrianus I Wayan Ilia Yuda Sukmana ${ }^{2}$ \\ ${ }^{1,2}$ Educational Technology Study Program, Ganesha University of Education, Sinagaraja, Indonesia \\ *Corresponding author: niluhsukareni16@undiksha.ac.id
}

\begin{abstract}
Abstrak
Masih banyak guru yang kesulitan dalam menggunakan teknologi mengembangkan bahan ajar yang dapat memfasilitasi siswa dalam belajar. Hal ini berdampak pada hasil belajar siswa yang rendah. Tujuan penelitian ini yaitu menciptakan Emodul dengan model pembelajaran problem-based learning. Jenis penelitian ini yaitu pengembangan dengan menggunakan model ADDIE. Subjek uji ahli terdiri dari 3 orang yaitu 1 ahli mata pelajaran, 1 ahli desain pembelajaran, dan 1 ahli media pembelajaran. Subjek uji coba produk terdiri dari 9 siswa. Metode yang digunakan dalam mengumpulkan data yaitu observasi, wawancara, dan kuesioner. Instrument yang digunakan dalam mengumpulkan data yaitu kuesioner. Teknik yang digunakan untuk menganalisis data yaitu analisis deskriptif kualitatif dan kuantitatif. Hasil penelitian yaitu Penilaian yang diberikan oleh ahli isi pelajaran yaitu 96,47 (sangat baik). Penilaian dari ahli desain pembelajaran yaitu 93,33\% (sangat baik). Penilaian dari ahli media pembelajaran yaitu 97,5\% (sangat baik). Hasil uji coba perorangan, yaitu 95,53\% (sangat baik), dan hasil uji coba kelompok kecil yaitu 95,53\% (sangat baik). Dapat disimpulkan bahwa E-modul dengan model pembelajaran problem-based learning valid dan layak diterapkan dalam proses pembelajaran. Implikasi penelitian ini yaitu E-modul dengan model PBL dapat digunakan guru dalam pembelajaran.
\end{abstract}

Kata kunci: E-modul, PBL, Bahasa Indonesia.

\section{Abstract}

There are still many teachers who have difficulty using technology to develop teaching materials that can facilitate students' learning. This has an impact on student learning outcomes are low. This study aims to develop E-module with problembased learning model. This type of research is development using the ADDIE model. The subject of the expert test consisted of 3 people, namely 1 subject expert, 1 learning design expert, and 1 learning media expert. The product trial subjects consisted of 9 students. The methods used in collecting data are observation, interviews, and questionnaires. The instrument used in collecting data is a questionnaire. The technique used to analyze the data is descriptive qualitative and quantitative analysis. The results of the study were the assessment given by the subject matter expert, which was 96.47 (very good). The assessment of learning design experts is $93.33 \%$ (very good). The assessment of learning media experts is $97.5 \%$ (very good).Individual trial results, that is $95.53 \%$ (very good), and the result of small group trial is $95.53 \%$ (very good). It can be concluded that E-modules with problem-based learning models are valid and feasible to be applied in the learning process. The implication of this research is that the E-module with the PBL model can be used by teachers in learning.

Keywords: E-module, PBL, Indonesian

$\begin{array}{ll}\text { History: } & \text { Publisher: Undiksha Press } \\ \text { Received : August } 02,2021 & \text { Licensed: This work is licensed under } \\ \text { Revised : August 03, 2021 } & \text { a Creative Commons Attribution 3.0 License } \\ \text { Accepted : October 13, } 2021 & \\ \text { Published : October 25, } 2021 & \text { CC (O) }\end{array}$

\section{INTRODUCTION}

The Covid-19 pandemic has had a tremendous impact on Indonesian education. The intensity of the spread of the Covid-19 virus is very fast, resulting in uncontrolled virus transmission and spreading globally (Handayani et al., 2020; Hincal \& Alsaadi, 2021). This is what causes learning activities that were originally face-to-face, are now turning into online learning (Alavudeen et al., 2021; Yulia, 2020). Policies made by the government regarding online learning must be carried out by all educational institutions. Teachers are expected to continue to carry out effective learning through online learning so that learning objectives can be achieved optimally (Azubuike et al., 2021; Kim \& Sihyun Park, 2021). Teachers are required to master the information technology needed in online learning so that learning activities can run optimally. In addition, teachers must be able to choose and apply appropriate learning models for online learning. Changes in the methods or learning models 
used by teachers in online learning will have an impact on the success of learning (Dong et al., 2020; Khan et al., 2021). The use of technology will enable learning even in different places. So that technology is very useful for optimizing the learning process (Davidi et al., 2021; Sprenger \& Schwaninger, 2021).

However, the problem that occurs today is that there are still many teachers who have difficulty using technology to develop teaching materials or learning media that can facilitate students in learning (Pangesti et al., 2017; Weng \& Chen, 2020). In addition, there are still many cases that are found regarding the management of classroom situations in online learning that still use the lecture method which makes students bored in learning (Hermanto et al., 2021; Syauqi et al., 2020). This problem was also found in one high school. Based on the results of observations and interviews conducted at the Undiksha Laboratory Junior High School, it was found that the problem was that the delivery of material often used the lecture method. This makes students feel bored in learning. Relying on the presentation of material from the teacher sacrifices the active role of students in the class, causing the material presented cannot be accepted as a whole by students. This is not in accordance with the 2013 curriculum which focuses more on students as the center of learning (Anif et al., 2020; Suyanto, 2018). In addition, based on the results of interviews with teachers, it was found that there is a lack of digital teaching materials in Indonesian subjects that can facilitate students in learning. This is because teachers are still having difficulties in developing digital teaching materials for students. This problem has an impact on student learning outcomes below the average, so that learning objectives are not achieved optimally.

The solution offered to overcome these problems is to develop interactive teaching materials that are in accordance with the 2013 curriculum. One of the interactive teaching materials that can be used is E-modules using a problem-based learning model. E-module is an electronic book that was developed with the aim that students can study independently (Liu et al., 2021; Seruni et al., 2020). The characteristics of the module are the same as the characteristics of the module, namely self-instruction (clear instructions), self-contained (learning material that can be studied alone), stand-alone (not dependent on other teaching materials), adaptive and user friendly (easy to use) (Asrial et al., 2020; Perdana et al., 2017). Learning by using E-modules will allow students to have a high learning speed. This is because students can learn independently and can access material anywhere (Komikesari et al., 2020; Ningsih \& Mahyuddin, 2021). In accessing the remaining E-modules, you can use electronic devices such as cellphones, laptops, or computers. The advantages of E-modules from printed teaching materials are that they are equipped with interactive media such as audio, video, animation and other interactive features that can be played and played back by students when using the E-module (Darmaji et al., 2019; Irwansyah et al., 2017b). This emodule can provide complete, interactive, and interactive material. E-modules combined with problem-based learning models will increase student activity in learning.

The problem-based learning model is a learning model that uses a real-world learning approach as a context for students to learn (Bosica et al., 2021; Seruni et al., 2020). The syntax of the problem-based learning model contains several stages of problem-solving strategies, namely finding problems, defining, collecting facts, compiling, investigating, perfecting problems, concluding, and testing problem solutions (Dewi et al., 2020; LaForce et al., 2017). The problem-based learning model focuses more on students as learning people. This learning model is supported by constructivism theory, where students are encouraged to develop their own knowledge (Hussin et al., 2018; Seruni et al., 2020). This learning model involves all students in learning so that it can increase student activity in learning (Astari et al., 2018; Devi \& Bayu, 2020). Students are also invited to solve problems given by the teacher so that they can improve critical thinking skills. The problem that will be given to 
students is an authentic problem so that students easily understand the problem and apply the solution in life (Bosica et al., 2021; Wulandari \& Suparno, 2020).

The findings of previous studies also state that E-modules can increase students' enthusiasm for learning (Aprilia \& Suryadarma, 2020; Mastroleo et al., 2020). Other research findings also state that E-modules can assist students in learning so as to improve student learning outcomes(Canboy et al., 2016; Hamid et al., 2021). Other research also states that PBL can increase student activity in learning (Hussin et al., 2018; LaForce et al., 2017). There is no study on the development of E-modules using a problem-based learning model. The advantage of the E-module with the problem-based learning model is that it is displayed with a flipbook so that it will give an interesting impression. In addition, this E-module is equipped with animation, video and audio that will attract students' attention in learning. The purpose of this study is to develop an E-module with a problem-based learning model. It is hoped that the E-module with a problem-based learning model can make it easier for students to learn independently.

\section{METHODS}

This type of research is development research. The model used in developing the Emodulewith a problem-based learning model, namely ADDIE which includes the stages of analysis, design, development, implementation, and evaluation (Alnajdi, 2018). This model is used because it is systematic, simple, and easy to understand so that it can facilitate developmentE-module with a problem-based learning model. The analysis phase was carried out by learning analysis. The design stage is carried out by developing an E-module flowchart. The development stage is developing an E-module. The implementation stage is implementing the E-module to determine the effectiveness of the E-module with a problembased learning model. E-module products will be reviewed by 3 experts, namely 1 learning content expert, 1 learning design expert, and 1 learning media expert. The product trial subjects were 9 people, which included 3 students for the individual test, and 6 students for the small group test. The methods used in collecting data are observation, interviews, and questionnaires. Observation and interview methods were carried out to find out the conditions or problems that were happening in learning. Questionnaire method is used to measure the feasibility of E-module productswith a problem-based learning model. The instrument used to collect data is a questionnaire. The questionnaire grids are presented in tables 1,2 , and 3 .

Table 1. Learning Content Expert Instrument Grid

\begin{tabular}{lll}
\hline No & \multicolumn{1}{c}{ Aspect } & \multicolumn{1}{c}{ Indicator } \\
\hline 1 & Curriculum & a. Identity \\
& & b. Learning indicators \\
2 & Method & c. Learning objectives \\
& & a. Conformity of material content \\
& b. Material systematic \\
3 & Language & c. Level of ease and depth of material \\
& & a. Information clarity \\
4 & Evaluation & b. Language Usage \\
& & c. Legibility \\
& & b. Cuestion difficulty level \\
\end{tabular}


Table 2. Learning Design Expert Instrument Grid

\begin{tabular}{lll}
\hline No & \multicolumn{1}{c}{ Aspect } & \multicolumn{1}{c}{ Indicator } \\
\hline 1 & Curriculum & a. Identity \\
& & b. Competence to be achieved \\
& & c. Clarity of learning objectives \\
& d. Information clarity \\
& \multirow{3}{*}{ Method } & a. Media Equipment \\
& bvaluation & b. Clarity of Learning Design \\
& & c. Clarity of Study Instructions \\
& a. Availability of learning evaluation \\
& b. The suitability of the question with the material \\
& c. Clarity of instructional evaluation instructions \\
\hline & &
\end{tabular}

Table 3. Learning Media Expert Instrument Grid

\begin{tabular}{|c|c|c|}
\hline No & Aspect & Indicator \\
\hline 1 & Text Message Design & $\begin{array}{l}\text { a. Accuracy of type/size of letters and punctuation } \\
\text { b. Text legibility } \\
\text { c. Word choice accuracy } \\
\text { d. Text color accuracy with background }\end{array}$ \\
\hline 2 & Picture Message Design & $\begin{array}{l}\text { a. The suitability of the image with the material } \\
\text { b. Availability of image captions } \\
\text { c. Easy to understand images } \\
\text { d. Image layout accuracy }\end{array}$ \\
\hline 3 & Video Message Design & $\begin{array}{l}\text { a. The suitability of the video with the material } \\
\text { b. Easy to understand videos } \\
\text { c. Information clarity }\end{array}$ \\
\hline 4 & Organizing E-Modules & $\begin{array}{l}\text { a. E-module is easy to use } \\
\text { b. Navigation consistency } \\
\text { c. Clear instructions for use }\end{array}$ \\
\hline
\end{tabular}

(Prawiladilaga, 2015)

The formula used in testing the validity of the instrument is Gregory. The technique used in analyzing the data is descriptive qualitative and quantitative analysis. Qualitative descriptive analysis technique was used in processing data from the results of expert trials and student test subjects, in the form of input to the questionnaire used in revising the Emodule product. Quantitative descriptive analysis techniques are used to process data in the form of assessments given by experts and students. In giving meaning and decision making used as a reference for the conversion level of achievement on a Five scale that shown in Table 5.

Table 4. Conservation Level Achievement Scale 5

\begin{tabular}{ccc}
\hline Achievement Rate (\%) & Qualification & Description \\
\hline $90-100$ & Very good & No need to revise \\
$75-89$ & Good & Slight revision \\
$65-79$ & Enough & Revised sufficiently \\
$55-64$ & Not enough & Many things have been revised \\
$0-54$ & Very less & Repeated product \\
\hline & & (Tegeh \& Jampel, 2017)
\end{tabular}




\section{RESULTS AND DISCUSSION}

\section{Results}

The first step is analysis. At this stage the activities carried out are curriculum analysis, student characteristics, competencies, learning activities and learning facilities. Based on the results of the curriculum analysis, the curriculum used is the 2013 curriculum. Based on the results of the analysis of student characteristics, information is obtained thatthe activeness of students in participating in the learning process tends to be low. The results of the competency analysis are the choice of maetri in even semester Indonesian language learning, namely inheriting noble values and creating folk poetry, appreciating and creating fables, correspondence with personal letters and official letters, and become effective readers. The choice of material was because the material was cut a lot due to UAS preparation, so students did not understand the material. The results of the analysis of learning activities are that students cannot learn independently because of the lack of interactive teaching materials that facilitate students. The results of the analysis of learning facilities, namely facilities such as internet access, cellphones, computer labs have been owned so that they can support learning.

The second stage is design. At this stage, the flowchart, Storyboard E-module is madewith a problem-based learning model, and develop assessment instruments, as well as learning implementation plans. Purposeflow chartand Storyborad, which is knowing the workflow of the E-module to be developed. The preparation of the E-module framework was carried out to describe the outline of the E-module and the systematics of the material. The function of this framework is to make it easier to compile the E-module that will be developed. In designing the appearance of this E-module, Arial typeface is used with a size of 50 points for the cover of the E-module and 12 points and the distance between lines is 1.5 so that students are easy to read the material presented in the E-module.

The third stage is development. At this stage it is developedE-module with a problembased learning model. The process of developing E-module products is carried out by collecting teaching materials, these materials are obtained from Indonesian class VII textbooks and other sources relevant to the material raised. All learning resources used to develop E-modules such as text, images, and videos are combined using the Flip PDF Professional application as the main program so that they become electronic teaching materials. After the materials for developing E-modules are combined and become complete teaching materials, then proceed with the manufacture of E-modules that can be accessed via laptops or computers. The results of the development of the E-module with the problembased learning model, presented in Figure 1.

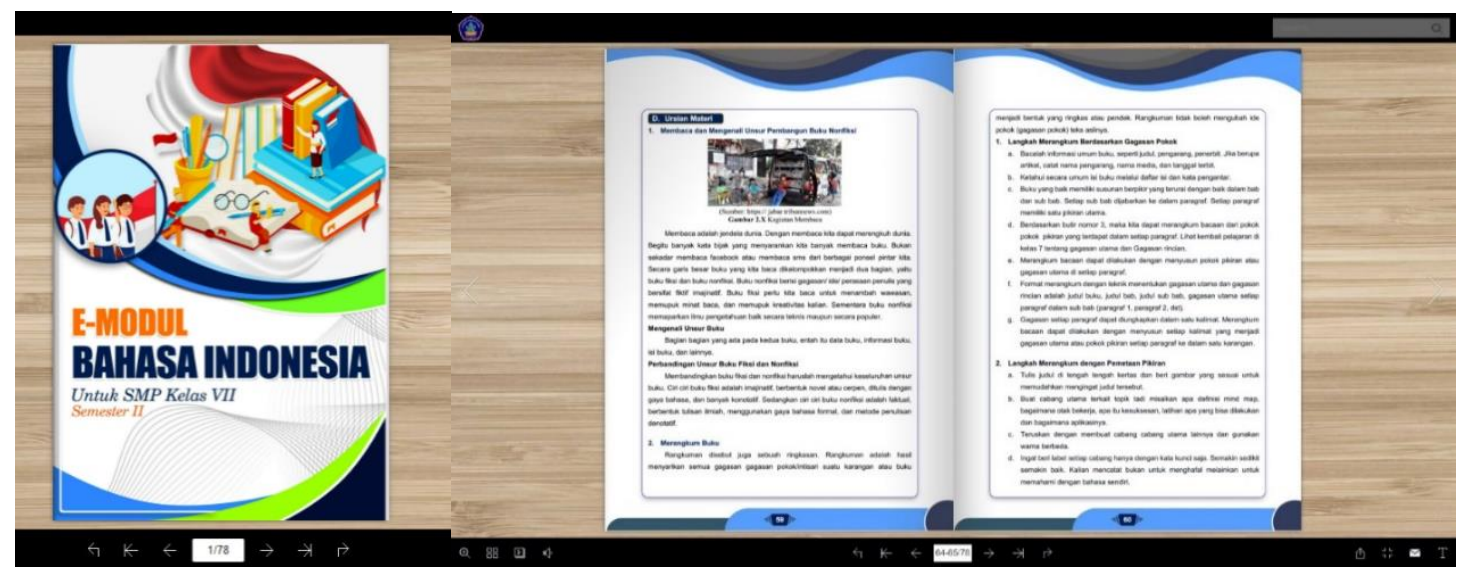

Figure 1. E-module with Problem-Based Learning Model 
After the media was developed further E-module with the problem-based learning learning model assessed by subject matter experts, learning design experts, and learning media experts. Based on the assessment given by subject matter experts, the level of achievement of the E-module with the problem-based learning model is $96.47 \%$ so that it gets very good qualifications. The assessment given by learning design experts is $93.33 \%$ so that they get very good qualifications. The results of the assessment given by learning media experts are $97.5 \%$ so that they get very good qualifications. It can be concluded that the Emodule with the problem-based learning model is suitable for use in the learning process. The inputs given by experts to improve the products developed are:Instructions for training and evaluation are made so that they are left aligned. On the front cover, give the identity of the bearer, even though on the back cover there is already an identity, and add the name of the supervisor on the back cover. The results of the revised E-module developed are presented in Figure 2.

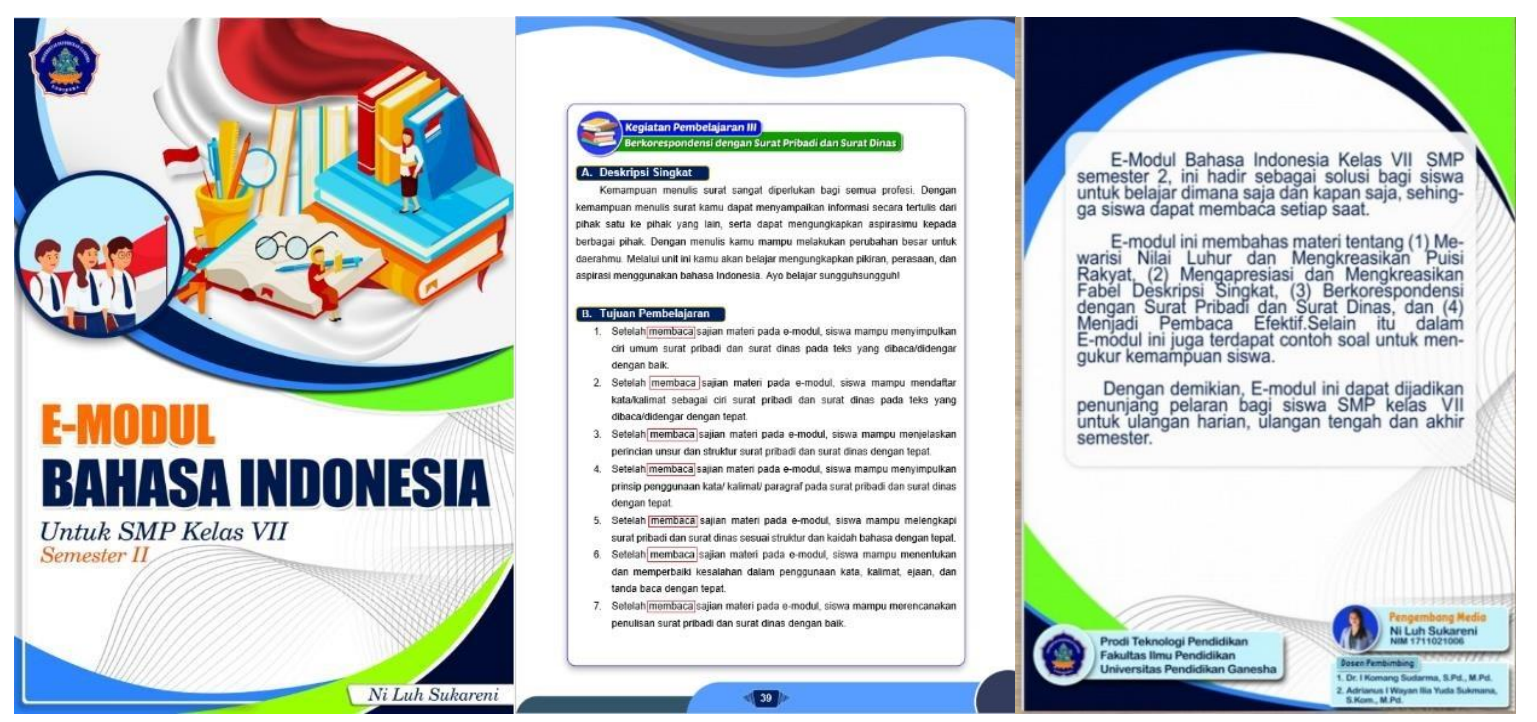

Figure 2. E-module After Revised

The next stage is implementation. At this stage, the implementation of product trials is carried out after being assessed by experts. Individual trial results, the percentage of learning outcomes of E-module learning outcomes based on each subject is $95.53 \%$ so that it gets very good qualifications. The results of small group trials, the percentage of achievement of learning outcomes for learning E-modules based on each subject is $95.53 \%$ so that they get very good qualifications. It can be concluded that the E-modulewith a feasible problem-based learning model, it does not need to be revised and is feasible to be applied in the learning process.

\section{Discussion}

E-module with the problem-based learning model, it gets very good qualifications and is suitable for use because in learning it is caused by the following factors. First, E-module the problem-based learning model is feasible to use because it gets very good qualifications. Obtaining a very good qualification was obtained because in the process of developing this E-module using a systematic development model with the ADDIE development model. Emodule development using the ADDIE model is effective to create products that are valid and suitable for use in the learning process (Pramana et al., 2020; Ula \& Fadila, 2018). In addition, E-modules get very good qualifications because the content presented is in accordance with learning. Obtaining a very good qualification can be achieved due to the 
clarity of identity, indicators, and learning objectives contained in the E-module.Clarity of subject identity, suitability of indicators, and learning objectives make it easier for students to understand the learning material (Kimianti \& Prasetyo, 2019; Wijayanti et al., 2016). The presentation of the material on the E-module is arranged by taking into account these aspects so as to produce an E-module that is in accordance with the learning objectives that have an impact on improving the quality of learning (Hamdunah et al., 2016; Hamid et al., 2021). Clarity of indicators and learning objectives can improve the quality of better learning (Astra et al., 2020; Fisnani et al., 2020).

Second, E-module the problem-based learning model is feasible to use because it makes it easier for students to learn. The presentation of the material is arranged in a coherent manner according to the mapping of the material so that the material is presented logically and systematically. The presentation of the material is equipped with pictures, learning videos, and a glossary so that the content of the material can be conveyed properly (Aufa et al., 2021; Yulando et al., 2019). This can make it easier for students to explore the content of the material presented (Fonda \& Sumargiyani, 2018; Syahroni et al., 2016). E-modules that are presented in accordance with the learning material will make it easier for students to understand the learning material (Mills et al., 2021; Sofyan et al., 2019). Thus, the developed E-module can attract students' attention, and can make it easier for students to understand the content of the subject matter.

Third, E-module the problem-based learning model is feasible to use because it increases students' enthusiasm for learning. The developed e-module also provides learning media such as videos that make students motivated in learning. The use of learning media such as videos can increase students' enthusiasm for learning (Andriyani \& Suniasih, 2021; Bajrami \& Ismaili, 2016; Van Alten et al., 2019). Videos will make it easier for students to understand the subject matter quickly (Gürsoy, 2021; Komalasari \& Rahmat, 2019). Presentation of material that is arranged in a coherent manner, and is equipped with the use of pictures, videos, and music can attract students' attention in learning, and can make it easier for students to understand the material (Colasante \& Douglas, 2016; Fisnani et al., 2020).

Fourth, the use of the PBL learning model also increases students' enthusiasm for learning. This learning model demands student activity so that it can increase student learning motivation (Nurtanto et al., 2019; Seruni et al., 2020). Students are invited to solve problems given by the teacher so that they can improve their critical thinking skills (Bosica et al., 2021; Wulandari \& Suparno, 2020). This ability will make it easier for students to solve the problems they are facing. The use of E-modules with problem-based learning models is effectively used to increase students' enthusiasm for learning.

The findings of previous research stated that E-modules can increase students' independence in learning so as to improve student learning outcomes (Irwansyah et al., 2017a; Lee \& Osman, 2012; Winatha et al., 2018). Other research findings also state that the PBL model can improve students' critical thinking skills (Nur et al., 2016; Umbara et al., 2020). The advantages of E-modules with problem-based learning models are that they can be accessed on mobile phones so that they are easy to carry everywhere by students and give an attractive impression. In addition, this E-module is equipped with animation, video and audio that will attract students' attention in learning. The implication of this research is that the teaching materials developed in the form of E-modules with problem-based learning models can be used by teachers in learning, so that they can help students in learning.

\section{CONCLUSION}

Based on the assessments given by experts and students, the teaching materials developed were very well qualified. It can be concluded that the E-module with the problem- 
based learning model is feasible to be applied in the learning process. This e-module can help students in self-study.

\section{REFERENCES}

Alavudeen, SS, Easwaran, V., Mir, JI, Shahrani, SM, Ahmed Mohammed Almodeer Aseeri, AA, Khan, NA, \& Asiri, AA (2021). The influence of COVID-19 related psychological and demographic variables on the effectiveness of e-learning among health care students in the southern region of Saudi Arabia. Saudi Pharmaceutical Journal. https://doi.org/10.1016/j.jsps.2021.05.009.

Alnajdi, SM (2018). The Effectiveness of Designing and Using a Practical Interactive Lesson based on ADDIE Model to Enhance Students' Learning Performances in University of Tabuk. Journal of Education and Learning, 7(6), 212. https://doi.org/10.5539/jel.v7n6p212.

Andriyani, NL, \& Suniasih, NW (2021). Development Of Learning Videos Based On Problem-Solving Characteristics Of Animals And Their Habitats Contain in Science Subjects On 6th-Grade. Journal of Education ..., 5(1), 37-47. https://doi.org/10.23887/jet.v5i1.32314.

Anif, S., Sutopo, A., \& Prayitno, HJ (2020). Lesson study validation: Model for social and natural sciences teacher development in the implementation of national curriculum in Muhammadiyah schools, Indonesia. Universal Journal of Educational Research, 8(1), 253-259. https://doi.org/10.13189/ujer.2020.080132.

Aprilia, I., \& Suryadarma, IGP (2020). E-Module of Mangrove Ecosystem (EMME): Development, Validation, and Effectiveness in Improving Students' Self-Regulated. Biosphere: Journal of Education, 13(1), 114-129. https://doi.org/10.21009/biosferjpb.v13n1.114-129.

Asrial, Syahrial, Maison, M., Kurniawan, DA, \& Piyana, SO (2020). Ethnoconstructivism EModule to Improve Perception, Interest, And Motivation of Students in Class V Elementary School. Indonesian Journal of Education, 9(1), 30-41. https://doi.org/10.23887/jpi-undiksha.v9i1.19222.

Astari, FA, Suroso, S., \& Yustinus, Y. (2018). The Effectiveness of Using Discovery Learning Models and Problem Based Learning Models on Science Learning Outcomes for Grade 3 Elementary School Students. Journal of Basicedu, 2(1), 1-10. https://doi.org/10.31004/basicedu.v2i1.20.

Astra, IM, Raihanati, R., \& Mujayanah, N. (2020). Development of Electronic Module Using Creative Problem-Solving Model Equipped with Hots Problems on The Kinetic Theory of Gases Material. Journal of Physical Education Research \& Development, 6(2), 181-194. https://doi.org/10.21009/1.06205.

Aufa, MN, Rusmansyah, R., Hasbie, M., Jaidie, A., \& Yunita, A. (2021). The Effect of Using e-module Model Problem Based Learning (PBL) Based on Wetland Environment on Critical Thinking Skills and Environmental Care Attitudes. Journal of Science Education Research, 7(3), 401-407. https://doi.org/10.29303/jppipa.v7i3.732.

Azubuike, OB, Adegboye, O., \& Quadri, H. (2021). Who gets to learn in a pandemic? Exploring the digital divide in remote learning during the COVID-19 pandemic in Nigeria. International Journal of Educational Research Open, 2-2. https://doi.org/10.1016/j.ijedro.2020.100022.

Bajrami, L., \& Ismaili, M. (2016). The Role of Video Materials in EFL Classrooms. Procedia - Social and Behavioral Sciences, 232(April), 502-506. https://doi.org/10.1016/j.sbspro.2016.10.068.

Bosica, J., S. Pyper, J., \& MacGregor, S. (2021). Incorporating problem-based learning in a 
secondary school mathematics preservice teacher education course. Teaching and Teacher Education, 102, 103335. https://doi.org/10.1016/j.tate.2021.103335.

Canboy, B., Montalvo, A., Buganza, MC, \& Emmerling, RJ (2016). 'Module 9': a new course to help students develop interdisciplinary projects using the framework of experiential learning theory. Innovations in Education and Teaching International, 53(4), 445-457. https://doi.org/10.1080/14703297.2014.975150.

Colasante, M., \& Douglas, K. (2016). Prepare-participate-connect: Active learning with video annotation. Australasian Journal of Educational Technology, 32(4), 68-91. https://doi.org/10.14742/ajet.2123.

Darmaji, Astalini, Kurniawan, DA, Parasdila, H., Iridianti, Susbiyanto, Kuswanto, \& Ikhlas, M. (2019). E-Module based problem solving in basic physics practicum for science process skills. International Journal of Online and Biomedical Engineering, 15(15), 417. https://doi.org/10.3991/ijoe.v15i15.10942.

Davidi, EIN, Sennen, E., \& Supardi, K. (2021). Integration of STEM (Science, Technology, Engineering and Mathematical) Approaches for Improving Critical Thinking Skills of Elementary School Students. Scholaria: Journal of Education and Culture, 11(1), 1122. https://doi.org/10.24246/j.js.2021.v11.i1.p11-22.

Devi, PS, \& Bayu, GW (2020). Critical Thinking and Science Learning Outcomes Through Visual Media Assisted Problem Based Learning. MIMBAR PGSD Undiksha, 8(2), 238-252. https://doi.org/10.23887/jjpgsd.v8i2.26525.

Dewi, SM, Gunawan, G., Harjono, A., Susilawati, S., \& Herayanti, L. (2020). Generative learning models assisted by virtual laboratory to improve mastery of student physics concept. Journal of Physics: Conference Series, 1521(2), 0-7. https://doi.org/10.1088/1742-6596/1521/2/022013.

Dong, C., Cao, S., \& Li, H. (2020). Young Children's Online Learning during COVID-19 Pandemic: Chinese Parents' Beliefs and Attitudes. Child Youth Serv Rev, 118. https://doi.org/10.1016/j.childyouth.2020.105440.

Fisnani, Y., Utanto, Y., \& Ahmadi, F. (2020). The Development of E-Module for Batik Local Content in Pekalongan Elementary School. Innovative Journal of Curriculum and Educational Technology, 9(1), 40-47. https://doi.org/10.15294/IJCET.V9I1.35592.

Fonda, A., \& Sumargiyani, S. (2018). The Developing Math Electronic Module With Scientific Approach Using Kvisoft Flipbook Maker Pro For Xi Grade Of Senior High School Students. Infinity Journal, 7(2), 109-122. https://doi.org/10.22460/infinity.v7i2.p109-122.

Gürsoy, G. (2021). Digital storytelling: Developing 21st century skills in science education. European Journal of Educational Research, 10(1), 97-113. https://doi.org/10.12973/EU-JER.10.1.97.

Hamdunah, Yunita, A., Zulkardi, \& Muhafzan. (2016). Development a Constructivist Module and Web on Circle and Sphere Material with Wingeom Software. Journal on Mathematics Education, 7(2), 109-116. https://doi.org/10.22342/jme.7.2.3536.109116.

Hamid, SNM, Lee, TT, Taha, H., Rahim, NA, \& Sharif, AM (2021). E-Content Module For Chemistry Massive Open Online Course (Mooc): Development And Students' Perceptions. Journal of Technology and Science Education, 11(1), 67-92. https://doi.org/10.3926/jotse.1074.

Handayani, D., Hadi, DR, Isbaniah, F., Burhan, E., \& Agustin, H. (2020). Corona virus disease 2019. Indonesian Journal of Respirology, 40(2), 119-129. https://doi.org/10.36497/jri.v40i2.101.

Hermanto, YB, Agustini, V., \& Srimulyani. (2021). The Challenges of Online Learning During the Covid-19 Pandemic. Journal of Education and Teaching, 54(1). 
https://doi.org/10.23887/jpp.v54i1.29703.

Hincal, E., \& Alsaadi, SH (2021). Stability analysis of fractional order model on corona transmission dynamics. Chaos, Solitons \& Fractals, 143, 110628. https://doi.org/10.1016/j.chaos.2020.110628.

Hussin, WNTW, Harun, J., \& Shukor, NA (2018). Problem Based Learning to Enhance Students' Critical Thinking Skills via Online Tools. Asian Social Science, 15(1), 14. https://doi.org/10.5539/ass.v15n1p14.

Irwansyah, FS, Lubab, I., Farida, I., \& Ramdhani, MA (2017a). Designing Interactive Electronic Module in Chemistry Lessons. Journal of Physics: Conference Series, 895(1). https://doi.org/10.1088/1742-6596/895/1/012009.

Irwansyah, Lubab, Farida, \& Ramdhani. (2017b). Designing Interactive Electronic Module in Chemistry Lessons F S. International Conference on Mathematics and Science Education (ICMScE), 895(1), 1-7. https://doi.org/10.1088/1742-6596/895/1/012009.

Khan, MA, Vivek, Nabi, MK, Khojah, M., \& Tahir, M. (2021). Students' Perception towards E-Learning During Covid-19 Pandemic In India: An Empirical Study. Sustainability, 13(1). https://doi.org/10.3390/su13010057.

Kim, S.-H., \& Sihyun Park. (2021). Influence of Learning Flow and Distance E-Learning Satisfaction on Learning Outcomes and the Moderated Mediation Effect of SocialEvaluative Anxiety in Nursing College Students during the COVID-19 Pandemic: A Cross-Sectional Study. Nurse Education in Practice, 6 (103197). https://doi.org/10.1016/j.nepr.2021.103197.

Kimianti, F., \& Prasetyo, ZK (2019). Development of Problem Based Learning-Based Science E-Modules to Improve Students' Scientific Literacy. Kwangsan: Journal of Educational Technology, 7(2), 91. https://doi.org/10.31800/jtp.kw.v7n2.p91--103.

Komalasari, K., \& Rahmat, R. (2019). Living Values Based Interactive Multimedia in Civic Education Learning. International Journal of Instruction, 12(1), 113-126. https://doi.org/10.29333/iji.2019.1218a.

Komikesari, H., Mutoharoh, M., Dewi, PS, Utami, GN, Anggraini, W., \& Himmah, EF (2020). Development of e-module using flip pdf professional on temperature and heat material. Journal of Physics: Conference Series, 1572(1). https://doi.org/10.1088/1742-6596/1572/1/012017.

LaForce, M., Noble, E., \& Blackwell, C. (2017). Problem-Based Learning (PBL) and Student Interest in STEM Careers: The Roles of Motivation and Ability Beliefs. Education Sciences, 7(4), 92. https://doi.org/10.3390/educsci7040092.

Lee, TT, \& Osman, K. (2012). Interactive Multimedia Module in the Learning of Electrochemistry: Effects on Students' Understanding and Motivation. Procedia Social and Behavioral Sciences, 46. https://doi.org/10.1016/j.sbspro.2012.05.295.

Liu, X., Kong, J., Jiang, M., \& Li, S. (2021). Interactive information module for person reidentification. Journal of Visual Communication and Image Representation, 75. https://doi.org/10.1016/j.jvcir.2021.103033.

Mastroleo, NR, Humm, L., Williams, CM, \& Kiluk, BD (2020). Initial testing of a computerbased simulation training module to support clinicians' acquisition of CBT skills for substance use disorder treatment. Journal of Substance Abuse Treatment, 114. https://doi.org/10.1016/j.jsat.2020.108014.

Mills, K., Roper, F., \& Cesare, S. (2021). Accelerating student learning in communication and research skills: the adoption of adaptive learning technologies for scenario-based modules. Technology, Change and the Academic Library, 75. https://doi.org/10.1016/B978-0-12-822807-4.00007-5.

Ningsih, SY, \& Mahyuddin, N. (2021). Thematic E-Module Design Based on Early Childhood Language Politeness in Kindergarten. Journal of Obsession: Journal of 
Early Childhood Education, 6(1), 137-149. https://doi.org/10.31004/obsesi.v6i1.1217. Nur, S., Pujiastuti, \& Rahman. (2016). Effectiveness of Problem Based Learning (PBL) Model on Student Learning Outcomes of Biology Education Study Program, University of West Sulawesi. Scientific Journal, 2(2), 133-141. https://doi.org/10.31605/saintfik.v2i2.105 .

Nurtanto, M., Sofyan, H., Fawaid, M., \& Rabiman, R. (2019). Problem-based learning (PBL) in industry 4.0: Improving learning quality through character-based literacy learning and life career skills (LL-LCS). Universal Journal of Educational Research, 7(11), 2487-2494. https://doi.org/10.13189/ujer.2019.071128.

Pangesti, KI, Yulianti, D., \& Sugianto. (2017). STEM-Based Teaching Materials (Science, Technology, Engineering, and Mathematics) to Improve Concept Mastery of High School Students. Unnes Physics Education Journal, 6(3), 54-58. https://doi.org/10.15294/upej.v6i3.19270.

Perdana, Sarwanto, Sukarmin, S., \& Sujadi, I. (2017). Development of E-Module Combining Science Process Skills And Dynamics Motion Material To Increasing Critical Thinking Skills And Improve Student Learning Motivation Senior High School. International Journal of Science and Applied Science, 1(1), 45-54. https://doi.org/10.20961/ijsascs.v1i1.5112.

Pramana, MWA, Jampel, IN, \& Pudjawan, K. (2020). Improving Biology Learning Outcomes Through Problem Based Learning-Based E-Modules. Undiksha Edutech Journal, 8(2), 17. https://doi.org/10.23887/jeu.v8i2.28921.

Prawiladilaga, DS (2015). Learning Design Principles (Instructional Design Principles). Prenadamedia Group.

Sanjaya, W. (2008). Learning System Planning and Design. Kencana Prenada Media Group.

Seruni, R., Munawaroh, S., Kurniadewi, F., \& Nurjayadi, M. (2020). Implementation of emodule flip PDF professional to improve students' critical thinking skills through problem based learning. Journal of Physics: Conference Series, 1521(4), 1-6. https://doi.org/10.1088/1742-6596/1521/4/042085.

Sofyan, H., Angereini, E., \& Saadiah, J. (2019). Development of E-Modules Based on Local Wisdom in Central Learning Model at Kindergartens in Jambi City. European Journal of Educational Research, 8(4), 1137-1143. https://doi.org/10.12973/eu-jer.8.4.1137.

Sprenger, DA, \& Schwaninger, A. (2021). Technology acceptance of four digital learning technologies (classroom response system, classroom chat, e-lectures, and mobile virtual reality) after three months' usage. International Journal of Educational Technology in Higher Education, 18(1), 1-17. https://doi.org/10.1186/s41239-02100243-4.

Suyanto, S. (2018). The Implementation Of The Scientific Approach Through 5ms Of The Revised Curriculum 2013 In Indonesia. Educational Horizons, 37(1), 22-29. https://doi.org/10.21831/cp.v37i1.18719.

Syahroni, MW, Dewi, NR, \& Kasmui. (2016). The Effect of Using Digimon (Science Digital Module) with Scientific Approach at the Visualization of Students' Independence and Learning Results. Indonesian Journal of Science Education, 5(1), 116-122. https://doi.org/10.15294/jpii.v5i1.5800.

Syauqi, K., Munadi, S., \& Triyono, MB (2020). Students' perceptions toward vocational education on online learning during the COVID-19 pandemic. International Journal of Evaluation and Research in Education (IJERE), 9(4), 881. https://doi.org/10.11591/ijere.v9i4.20766.

Tegeh and Jampel. (2017). Development Research Methods. Ganesha University of Education.

Ula, IR, \& Fadila, A. (2018). Development of E-Module Based on Learning Content 
Development System The subject matter of SMP Number Patterns. Decimal: Journal of Mathematics, 1(2), 201. https://doi.org/10.24042/djm.v1i2.2563.

Umbara, IAAP, Sujana, IW, \& Negara, IGAO (2020). Problem Based Learning Learning Model Assisted by Picture Series Media Influences on Students' Social Science Knowledge Competence. Journal of the Pulpit of Science, 25(2), 13-25. https://doi.org/10.23887/mi.v25i2.25154.

Van Alten, DCD, Phielix, C., Janssen, J., \& Kester, L. (2019). Effects of flipping the classroom on learning outcomes and satisfaction: A meta-analysis. Educational Research Review, 28(June), 1-18. https://doi.org/10.1016/j.edurev.2019.05.003.

Weng, SS, \& Chen, HC (2020). Exploring the role of deep learning technology in the sustainable development of the music production industry. Sustainability (Switzerland), 12(2), 1-20. https://doi.org/10.3390/su12020625.

Wijayanti, NPA, Damayanthi, LPE, Sunarya, IMG, \& Putrama, IM (2016). Development of Project Based Learning-Based E-Modules in Digital Simulation Subjects for Class X Students Case Studies at SMK Negeri 2 Singaraja. Journal of Technological And Vocational Education, 13(2), 184-197. https://doi.org/10.23887/jptkundiksha.v13i2.8526.

Winatha, KR, Naswan, S., \& Ketut, A. (2018). Development of Project-Based Interactive Emodules in Class X Digital Simulation Subjects at SMK TI Bali Global Singaraja. Indonesian Journal of Learning Technology, 8(1). https://doi.org/10.23887/jtpi.v8i1.2238.

Wulandari, A., \& Suparno, S. (2020). The Effect of Problem Based Learning Model on the Ability of Early Childhood Cooperation Character. Obsession Journal: Journal of Early Childhood Education, 4(2). https://doi.org/10.31004/obsesi.v4i2.448.

Yulando, S., Sutopo, S., \& Franklin Chi, T. (2019). Electronic Module Design and Development: An Interactive Learning. American Journal of Educational Research, 7(10), 694-698. https://doi.org/10.12691/education-7-10-4.

Yulia, H. (2020). Online Learning to Prevent the Spread of Pandemic Corona Virus in Indonesia. ETERNAL (English Teaching Journal), 11(1). https://doi.org/10.26877/eternal.v11i1.6068. 